\title{
Heyrnartaugaslíðursæxli á Íslandi i 30 ár (1979-2009)
}

Porsteinn H. Guðmundsson¹ læknakandídat, Hannes Petersen ${ }^{1,2}$ læknir

\section{ÁGRIP}

Inngangur: Heyrnartaugaslíðursæxli (acoustic neuroma (AN)) er æxli í 8. heilataug og á uppruna sinn frá taugaslíđursfrumum. Tilgangur rannsóknarinnar er að kanna nýgengið tímabilið 1979-2009 og varpa ljósi á faraldsfræðilega pætti er snúa að greiningu og meðferð.

Efniviður og aðferðir: Rannsóknin var afturskyggn og náđi til peirra sem greinst höfðu árin 1979-2009. Gögnum frá Heyrnar- og talmeinastöð Íslands (HTí), Sjúkratryggingum Íslands (Sí), háls-, nef- og eyrnadeild og heila- og taugaskurðdeild Landspítala (LSH) var safnað saman og athugaðir voru faraldsfræðilegir pættir sjúklingahópsins.

Niðurstöður: Nýgengi heyrnartaugaslíðursæxla 1979-2009 er

1,24/100.000/ári og fer vaxandi. 10\% æxla eru greind fyrir tilviljun,

flest á síðasta priðjungi tímabilsins, en á pví tímabili eru æxlin minni við greiningu, pað er fleiri meðalstór æxli finnast en færri stór og risastór.
Helstu einkenni sjúklinga eru heyrnarskerðing (69\%), jafnvægisleysi og/ eða svimi (47\%) og suð í eyrum (43\%). 47 einstaklingar fóru í skurðaðgerð, 16 fengu gammahnífsgeislun og 30 eru undir eftirliti. Fylgikvillar aðgerðar, með tilliti til heyrnar og andlitslömunar, voru skráđir í 39 tilfellum. Heyrnarleysi á aðgerðareyra var $69 \%(n=27)$ og $44 \%(n=17)$ hlutu óafturkræfa andlitslömun. Meðaleftirfylgni einstaklinga í eftirliti voru 3,5 ár og uxu 17\% æxlanna.

Álykun: Nýgengi heyrnartaugaslíðursæxla á Íslandi er svipað og á hinum Norðurlöndunum. Tilfellum fer fjölgandi og fleiri æxli greinast fyrir tilviljun sem meðal annars má pakka segulómtækninni. Ef æxli eru smá er eftirlit raunhæfur kostur par sem lágt hlutfall æxla stækkar innan nokkurra ára. Stæri æxli eru meðhöndluð með aðgerð eða gammahnífsgeislun en yfir helmingur aðgerðarsjúklinga missir heyrn eftir aðgerð.
Fyrirspurnir:

\section{Inngangur}

Heyrnartaugaslíðursæxli (e. acoustic neuroma) er góðkynja æxli sem á uppruna sinn í taugaslíðursfrumum 8 . heilataugar og er pví einnig kallað vestibular schwannoma. Heyrnartaugaslíðursæxli eru sex prósent allra innankúpuæxla. ${ }^{1}$ Vöxtur æxlisins er í fyrstu takmarkaður við innri hlustargang par sem pað prýstir á heyrnarhluta 8 . heilataugar og veldur heyrnarskerðingu og eyrnasuði. ${ }^{2}$ Að auki er um að ræða áverka á jafnvægisskynhluta 8. heilataugar með minnkun á leiðni jafnvægisskyns. Par sem petta gerist hægt, ná sjúklingar venjulega að aðlagast pesssari skertu starfsemi en annars koma fram jafnvægistruflanir. ${ }^{3,4}$ Nýgengi heyrnartaugaslíðursæxla hefur, samkvæmt erlendum rannsóknum, verið á bilinu 0,5-2,0/100.000/ári og farið vaxandi. Samfara aukinni tíðni hafa fundist smærri æxli við greiningu og fleiri finnast fyrir tilviljun. 5,6,7,8, Talið er að rekja megi aukna tíðni heyrnartaugaslíðursæxla og minni stærð æxla við greiningu að hluta til betri greiningaraðferða, einkum með tilkomu og aukinni notkun segulómskoðunar. ${ }^{10}$

Eftirfylgni og meðferð sjúklinga er prenns konar: Reglulegt eftirlit á vexti æxlisins með myndgreiningu, gammahnífsgeislun eða skurðaðgerð. Við val meðferðar parf að hafa í huga ýmsa pætti. Peir helstu eru stærð æxlis, aldur sjúklinga, einkenni, heilsufar og vilji sjúklings. Í mörgum tilfellum eru pessi æxli smá ( $<10 \mathrm{~mm})$ og hafa ekki nein vandkvæði í för með sér (tilviljanakennd greining) og er pá oftast fylgst með vexti æxlisins reglulega. Helstu ábendingar gammahnífsgeislunar eða aðgerðar eru ungur aldur við greiningu, vöxtur æxlis með minnkun á heyrn eða aukning jafnvægistruflana. Í meðferð meðalstórra æxla (10-25 mm) er farið eftir aldri og vilja sjúklings ásamt fleiri atriðum, en í flestum tilfellum er valin gammahnífsgeislun eða aðgerð. ${ }^{3}$

Í pessari rannsókn var faraldsfræði heyrnartaugaslíðursæxla á Íslandi könnuð yfir 30 ára tímabil (1979 2009). Rannsóknin tekur tillit til sjúkdóms meðal heillar pjóðar par sem allir sem greinst hafa með heyrnartaugaslíðursæxli hafa komið á háls-, nef- og eyrnadeild og heila- og taugaskurðdeild LSH eða HTÍ auk pess sem SÍ veita upplýsingar um sjúklinga sem fóru í meðferð erlendis. Markmið rannsóknarinnar var að kanna með afturskyggnum hætti sjúkraskrár einstaklinga sem greinst höfðu með heyrnartaugaslíðursæxli á pessu tímabili. Skráð voru einkenni og stærð æxla við greiningu, fjöldi tilfella eftir tímabilum og hvaða meðferðarkostur var valinn.

\section{Efniviður og aðferðir}

Gagnaöflun

Í fyrstu hófst umfangsmikil leit að pýði einstaklinga sem greinst hafa með æxlið síðastliðin 30 ár. Til pess purfti staðfest greining að liggja fyrir, annaðhvort með vefjasýni eða myndgreiningu. Leitað var í gögnum LSH og HTÍ og fenginn listi frá SÍ yfir pá sem hlutu meðferð erlendis. Við pessa leit fundust 103 manns með greininguna heyrnartaugaslíðursæxli. Úr sjúkraskrám pessara einstaklinga voru fengnar upplýsingar um dagsetningu greiningar, einkenni við greiningu, hvort greining hafi verið fyrir tilviljun, stærð æxlis við greiningu, með- 
ferð og ástand sjúklings eftir meðferð, ásamt heyrnarmælingum fyrir og eftir meðferð.

Úrvinnsla á niðurstöðum og tölfræðileg úrvinnsla var gerð í Microsoft Excel og SPSS. Beitt var lýsandi tölfræði. Nýgengi var fundið með upplýsingum um meðaltalsmannfjölda á hverju 10 ára tímabili frá Hagstofu Íslands.

Áður en rannsóknin hófst fengust öll tilskilin leyfi frá Vísindasiðanefnd og Persónuvernd.

\section{Niðurstöður}

\section{Faraldsfræði}

103 einstaklingar með staðfesta greiningu heyrnartaugaslíðursæxla fundust. Í tilfelli 13 einstaklinga lá ekki nákvæmlega fyrir innan hvaða tímabils peir hefðu greinst og var tekið tillit til pess við útreikninga nýgengis milli pessara 10 ára tímabila. Nýgengi heyrnartaugaslíðursæxla yfir petta 30 ára tímabil var 1,24/100.000/ ári og ef rannsóknartímabilinu er skipt í prjú tímabil (1979-1988, 1989-1998 og 1999-2009) sést greinileg aukning í nýgengi (tafla I, mynd 1). Gerð var Poisson regression fyrir nýgengi milli pessara priggja tímabila og reyndist aukning nýgengis milli tímabila marktæk ( $\mathrm{p}<0,001)$. Tölvusneiðmynda- og segulómtækjum hefur á pessu tímabili farið fjölgandi, úr tveimur í 14 (mynd 1). Meðalaldur við greiningu var 52 ár (staðalfrávik 17 ár) og aldursdreifing á bilinu 15-84 ára. Meðalaldur við greiningu fyrstu 10 árin voru 56 ár, næstu 10 ár var meðalaldurinn 53 og síðasta tímabilið 52 ár og hefur pví farið lítillega lækkandi en munurinn reyndist ekki marktækur $(p=0,69)$. Áttatíu og níu einstaklingar voru með skráð einkenni við greiningu. Níu æxli (10\%) fundust fyrir tilviljun vegna myndrannsóknar á höfði með aðra ábendingu. Pessum tilviljunarkenndu æxlum fjölgaði einnig eftir tímabilum (mynd 2).

Stærð heyrnartaugaslíðursæxla við greiningu var gefin upp í 81 tilviki og flokkuð í fjóra stærðarflokka: Smá (1-10 mm, n=25), meðalstór (11-25 mm, n=31), stór (26-40 mm, n=23) og risastór æxli (>40 mm, n=2). ${ }^{3}$ Tafla II sýnir að æxli við greiningu eru minni par sem fleiri meðalstór æxli finnast en færri stór og risastór. Í peim 80 tilfellum par sem einkenni sjúklinga við greiningu koma fram í sjúkraskrám kvörtuðu flestir yfir heyrnarskerðingu (69\%), jafnvægisleysi og/eða svima (47\%) og suði í eyrum (43\%).

Á tímabilinu hafa 47 einstaklingar farið í skurðaðgerð, 16 í gammahnífsgeislun og 30 var fylgt eftir með myndgreiningu. Útilokaðir voru tveir sem fyrirhugað var að meðhöndla með gammahnífsgeislun og höfðu áður verið í eftirliti. Ekki fundust upplýsingar um meðferð hjá 8 einstaklingum. Ástand sjúklinga eftir aðgerð var fundið með afturvirkum hætti. Í 39 af 47 tilfellum lágu fyrir upplýsingar um heyrn eftir aðgerð og af peim höfðu $69 \%$ ( $n=27)$ misst heyrn eftir aðgerð og 44\% ( $n=17)$ hlutu óafturkræfa andlitslömun. Undanskildir eru peir sem höfðu andlitslömun eða heyrnarmissi fyrir aðgerð.
Nýgengi heyrnartaugaslíoursaxla 1979-2009

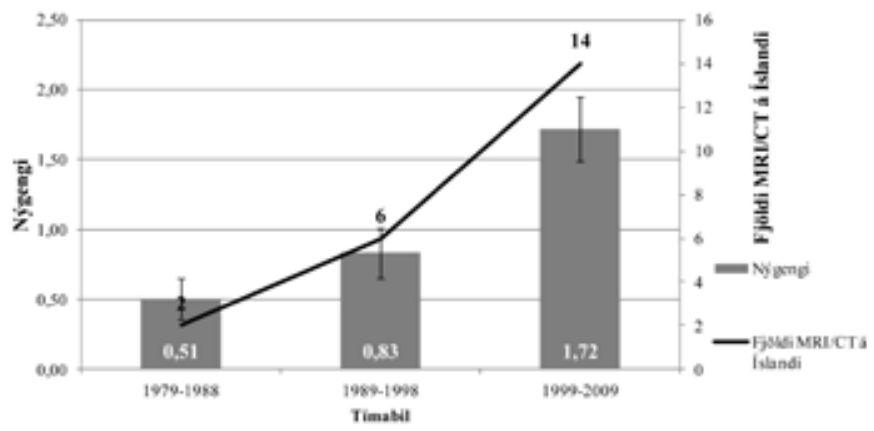

Mynd 1: Gráu súlurnar sýna nýgengi heyrnartaugaslíðursæxla/100.000/ári á Íslandi ásamt staðalskekkju nýgengis á premur 10 ára tímabilum. Svarta línan sýnir fjölda tölvusneiðmynda- og segulómtækja á Íslandi fyrir samsvarandi tímabil.

Til að fylgjast með breytingu á stærð æxla hjá einstaklingum í eftirliti purftu tvær eða fleiri myndgreiningarrannsóknir, segulómun eða tölvusneiðmynd, að liggja fyrir. Pessar upplýsingar lágu fyrir hjá 23 einstaklingum, par með talinn einn með tvíhliða heyrnartaugaslíðursæxli. Ýmist eru gefnar upp ein, tvær eða prjár stærðir á æxlinu en til að koma í veg fyrir skekkju er hæsta talan aðeins tekin með og athuguð stækkun eða minnkun á henni milli fyrstu og síðustu myndgreiningarrannsóknar. Marktæk stækkun eða minnkun telst vera $2 \mathrm{~mm}$ breyting eða meira miðað við aðrar rannsóknir. ${ }^{11}$ Meðaleftirfylgni í dögum var reiknuð út frá dagsetningu fyrstu og síðustu myndgreiningarrannsóknar. Pannig fékkst að meðallengd eftirlits var 1286 dagar eða 3,5 ár. Eftirlit leiddi í ljós að $17 \%$ æxla stækkuðu, $21 \%$ minnkuðu en $61 \%$ voru óbreytt аð stærð.

\section{Umræơur}

Nýgengi heyrnartaugaslíðursæxla á Íslandi frá 1979-2009 er 1,24/100.000/ári og er pví svipuð og annars staðar.,5,7 Nýleg rannsókn sýnir að nýgengi á Norðurlöndunum (Danmörku, Noregi, Svípjóð og Finnlandi) frá 1987-2007 var frá 0,6 til 1,2/100.000/ári. ${ }^{9}$ Hækkandi nýgengistölur sjást einnig yfir petta 30 ára tímabil eins og aðrar rannsóknir hafa gefið til kynna. ${ }^{6,78}$

Óljóst er hvort um vanmat á nýgengi sé að ræða. Einstaklingar í eftirliti gætu verið utan við okkar gagnaleit en pó hafa flestir með petta vandamál sótt pjónustu á LSH, HTÍ og meðferð erlendis í gegnum SÍ. Staðfest vefjagreining á æxlinu er í fæstum tilfellum til staðar par sem flestar skurðaðgerðir voru framkvæmdar erlendis. Petta á einkum við um pá sjúklinga sem gangast undir eftirlit og reynir pá á kunnáttu röntgenlækna að mismunagreina heyrnartaugaslíðursæxli frá öðrum fyrirferðum á svipuðu svæði. Að auki fæst ekki vefjagreining hjá peim sjúklingum sem gengust undir

Tafla I: Nýgengi heyrnartaugaslídursæxla/100.000/ári frá 1979-2009 ásamt staðalskekkju nýgengis. Borin eru saman tímabilin 1979-1988, 1989-1998 og 1999-2009.

\begin{tabular}{lccc}
\hline Tímabil & Fjöldi & Meðalmannfjöldi 0-100 ára & Nýgengi (Cl) \\
\hline $1979-1988$ & 12 & 237.571 & $0.505(0,287-0,889)$ \\
\hline $1989-1998$ & 22 & 263.741 & 0,146 \\
\hline $1999-2009$ & 56 & 296.637 & 0,178 \\
\hline
\end{tabular}


Exli fundin fyrir tilviljun, dreifing eftir tímabilum

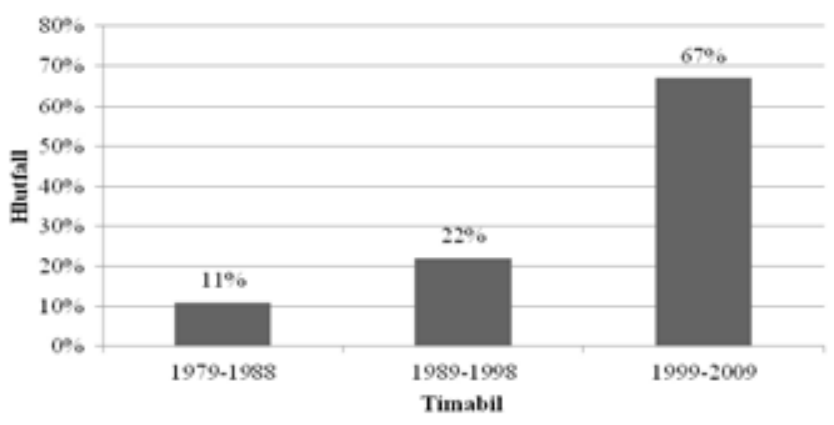

Mynd 2: Stöplaritið sýnir dreifingu tilviljunarkennds fundar á æxlinu innan pessara priggja tímabila.

gammahnífsgeislun. Pví er greining pessa sjúkdóms oftar klínísk en vefjafræðileg og getur pað haft áhrif á nýgengi.

Tafla II sýnir að fundist hafa hlutfallslega færri stór og risastór æxli við greiningu en áđur. Samanburður við rannsókn frá Danmörku sýnir að hér eru greind ívið færri smá æxli, töluvert fleiri stór og meðalstór en mun minna af risastórum æxlum. ${ }^{8,10}$ Tíðni tilviljunarkenndrar greiningar er 10\% sem er svipað og sýnt hefur verið fram á annars staðar. Til að mynda sýndi álíka stór rannsókn á 120 einstaklingum að $12 \%$ æxla hafi fundist fyrir tilviljun. ${ }^{12}$ Við greiningu var heyrnarskerðing aðalkvörtun hjá 69\% einstaklinga. Petta er í samræmi við aðrar rannsóknir par sem heyrnarskerðing er aðalumkvörtunarefni sjúklinga í allt að 60-75\% tilvika og við nánari uppvinnslu hefur verið sýnt fram á heyrnardeyfu í allt að 90-95\% sjúklinga. ${ }^{13,14,15}$

Hlutfall heyrnarmissis eftir skurðaðgerð er $69 \%$ í pessari rannsókn. Pessi tala gæti verið hærri par sem ekki er vitað í 8 tilfellum hvernig aðgerð var framkvæmd en aðgerðartækni er afgerandi hvað varðar varðveislu heyrnar eftir aðgerð. Aðrar rannsóknir hafa sýnt hærra hlutfall heyrnarskerðingar, ein peirra sýndi heyrnarmissi á aðgerðareyra í 85,6\% tilfella. ${ }^{16}$ Óafturkræf andlitslömun á sér stað í $44 \%$ tilfella en aðrar rannsóknir hafa sýnt hlutfall frá $20 \%$ til $46 \%{ }^{17,18}$ Er pá miðað við stig III (House-Brackmann skalinn ${ }^{19}$ ) eða lægra en í pessari rannsókn var um augljósa andlitslömun að ræða (> stig II). Í pessari rannsókn lá ekki fyrir hlutfall pessara fylgikvilla eftir gammahnífsgeislun en nýlegar rannsóknir hafa sýnt varðveislu heyrnar í 50-89\% tilfella (Gardner-Robertson I-III) og virkni andlitstaugar í 96-99\% tilfella (House-Brackmann I-II). ${ }^{13}$ Yfir lengri tíma virðist petta hlutfall hins vegar lækka en rannsókn á 216 einstaklingum sýndi 71\% varðveislu heyrnar innan priggja ára en eftir 10 ár var hlutfallið $44 \%{ }^{11}$
Tafla II: Taflan sýnir breytingu á stærð æxla innan tímabilanna priggja.

\begin{tabular}{lccc}
\hline Tímabil & $1979-1988$ & $1989-1998$ & $1999-2009$ \\
\hline Smá $(1-10 \mathrm{~mm})$ & $\mathrm{n}(\%)$ & $\mathrm{n}(\%)$ & $\mathrm{n}(\%)$ \\
\hline Međalstór $(11-25 \mathrm{~mm})$ & $1(37,5)$ & $5(26,3)$ & $17(31,5)$ \\
\hline Stór $(26-40 \mathrm{~mm})$ & $1(12,5)$ & $5(26,3)$ & $25(46,3)$ \\
\hline Risastór $(>40 \mathrm{~mm})$ & $3(37,5)$ & $8(42,1)$ & $12(22,2)$ \\
\hline & $1(12,5)$ & $1(5,3)$ & $0(0)$
\end{tabular}

Hlutfall stækkandi æxla við eftirlit er svipað og í öðrum rannsóknum með álíka lengd eftirfylgni. Pess má geta að í okkar rannsókn skorti upplýsingar í niðurstöðum myndgreiningarrannsókna um pað hvort æxlin voru takmörkuð við eða vaxin út fyrir innri hlustargang. Rannsókn frá Danmörku par sem meðaleftirfylgni var 3,6 ár, sýndi stækkun $28,9 \%$ æxla sem voru vaxin út fyrir innri hlustargang og $17 \%$ æxla sem voru takmörkuð við innri hlustargang. ${ }^{20}$ Önnur rannsókn par sem sjúklingum var fylgt eftir í 2,6 ár sýnir vöxt í $21 \%$ tilfella. ${ }^{21}$ Hærra hlutfall kemur fram í fjölgreiningarrannsókn par sem 43\% æxla uxu á 3,2 árum að meðaltali. ${ }^{22}$ Ekki er vitað hversu margir af peim sem fóru í aðgerð eða gammahnífsgeislun voru í upphafi í eftirliti, svo að hlutfall stækkaðra æxla gæti verið hærra. Í 22\% tilfella varð marktæk minnkun á æxlinu en orsök pess má að hluta rekja til blæðinga í æxlinu á fyrri myndgreiningum sem síðan hafa dregist saman. Aðrar rannsóknir hafa sýnt að eftirlit leiðir í ljós að um $10 \%$ æxla minnki. ${ }^{20,21,22}$

\section{Ályktun}

Nýgengi heyrnartaugaslíðursæxla á Íslandi er svipað og á Norðurlöndunum. Tilfellum fer fjölgandi og fleiri æxli greinast fyrir tilviljun. Petta má að mörgu leyti skýra með aukinni notkun á tölvusneiðmynda- og segulómtækni. Ef æxli eru smá er eftirlit raunhæfur kostur par sem lágt hlutfall æxla stækkar innan nokkurra ára. Stærri æxli voru meðhöndluð með aðgerð en yfir helmingur aðgerðarsjúklinga missir heyrn eftir aðgerð. Pví hefur gammahnífsgeislun reynst raunhæft úrræði við meðhöndlun pessara stærri æxla par sem tíðni fylgikvilla er mun lægri.

\section{Pakkarorð}

Pakkir fyrir pennan hluta rannsóknarinnar fá Halldór Baldursson hjá Sjúkratryggingum Íslands fyrir að taka saman lista yfir pá einstaklinga sem farið hafa í meðferð erlendis, Ingvar Hákon Ólafsson, Sigurður Stefánsson og Ingibjörg Hjálmarsdóttir fyrir öflun upplýsinga um pýðið og Krisján Óli Jónsson fyrir tölfræðiúrvinnslu. 


\section{Heimildir}

1. Anderson, T. D., L. A. Loevner, et al. (2000). „Prevalence of unsuspected acoustic neuroma found by magnetic resonance imaging." Otolaryngol Head Neck Surg 122(5): 643-6.

2. Spoelhof GD. When to suspect an acoustic neuroma. Am Fam Physician 1995; 52(6): 1768-74.

3. Bird PA, MacFarlane MR. Management of unilateral vestibular schwannoma/acoustic neuroma. The New Zealand medical journal 2007; 120:1265.

4. Bronstein AM. Vision and vertigo: some visual aspects of vestibular disorders. J Neurol. 2004; 251: 381-7.

5. Moffat DA, Jones SE, Mahendran S, Humphriss R, Baguley DM. Referral patterns in vestibular schwannomas, 10 years on. Clin Otolaryngol Allied Sci. 2004; 29(5): 515-7.

6. Tos M, Thomsen J, Charabi S. Incidence of acoustic neuromas. Ear Nose Throat J. 1992; 71: 391-3.

7. Tos M, Charabi S, Thomsen J. Incidence of vestibular schwannomas. Laryngoscope 1999; 109: 736-40.

8. Tos M, Stangerup SE, Cayé-Thomasen P, Tos T, Thomsen $\mathrm{J}$. What is the real incidence of vestibular schwannoma? Archives of Otolaryngology-Head \& Neck Surgery 2004 130(2): 216-20.

9. Larjavaara S, Feychting M, Sankila R, Johansen C, Klaeboe $\mathrm{L}$, Schüz J, Auvinen A. Incidence trends of vestibular schwannomas in Denmark, Finland, Norway and Sweden in 1987-2007. Br J Cancer. 2011; 105(7): 1069-75.
10. Stangerup SE, Tos M, Caye-Thomasen $\mathrm{P}$, Tos T, Klokker $\mathrm{M}$, Thomsen J. Increasing annual incidence of vestibular schwannoma and age at diagnosis. J Laryngol Otol. 2004, 118(8): 622-7.

11. Chopra R, Kondziolka D, Niranjan A, Lunsford LD, Flickinger JC. Long-term follow-up of acoustic schwannoma radiosurgery with marginal tumor doses of 12 to 13 Gy. Int J Radiat Oncol Biol Phys. 2007; 68(3): 845-51.

12. Jeyakumar A, Seth R, Brickman TM, Dutcher P. The prevalence and clinical course of patients with ,incidental' acoustic neuromas. Acta Otolaryngol. 2007; 127(10): 1051-

13. Myrseth E, Pedersen PH, Møller P, Lund-Johansen M. Treatment of vestibular schwannomas. Why, when and how? Acta Neurochir (Wien) 2007; 149(7): 647-60.

14. Hain TC Acoustic neuroma Northwestern University Medical School Chicago 2008. Updated Feb 16, 2009. www.dizziness-and-balance.com/disorders/tumors/ acoustic_neuroma.htm - apríl 2009.

15. Hoffman RA. Neurotologic evaluation and managemen of acoustic neuroma. Bull N Y Acad Med. 1979; 55(8): 751-

16. Karpinos M, Teh BS, Zeck O, Carpenter LS, Phan C, Mai WY, et al. Treatment of acoustic neuroma: stereotactic radiosurgery vs. microsurgery. Int J Radiat Oncol Biol Phys. 2002; 54(5): 1410-21.
17. Myrseth E, Møller P, Pedersen PH, Lund-Johansen M. Vestibular Schwannoma: Surgery or Gamma Knife Radiosurgery? A Prospective, Nonrandomized Study. Neurosurgery 2009; 64(4): 654-61.

18. Myrseth E, Møller P, Pedersen PH, Vassbotn FS, WentzelLarsen T, Lund-Johansen M. Vestibular schwannomas: Clinical results and quality of life after microsurgery or gamma knife radiosurgery. Neurosurgery 2005; 56(5): 92734

19. House JW, Brackmann DE. Facial nerve grading system. Otolaryngol Head Neck Surg. Apr 1985; 93(2): 146-7.

20. Stangerup SE, Caye-Thomasen P, Tos M, Thomsen J. The natural history of vestibular schwannoma. Otol Neurotol. 2006; 27(4): 547-52.

21. Solares CA, Panizza B. Vestibular schwannoma: An understanding of growth should influence management decisions. Otology \& Neurotology 2008; 29(6): 829-34.

22. Smouha EE, Yoo M, Mohr K, Davis RP. Conservative management of acoustic neuroma: a meta-analysis and proposed treatment algorithm. Laryngoscope. 2005; 115(3): 450-4.

\section{ENGLISH SUMMARY}

\section{Acoustic Neuroma in Iceland for 30 years (1979-2009)}

Gudmundsson $\mathrm{ThH}^{1}$, Petersen $\mathrm{H}^{1,2}$

Introduction: Acoustic neuroma (AN) is a tumor of the 8th cranial nerve. The goal of this study was to find the incidence of AN in Iceland from $1979-2009$ as well as investigate other epidemiological factors.

Material and Methods: The group of patients with the AN diagnosis was gathered retrospectively through medical records. We looked at several epidemiological factors including age and symptoms at diagnosis, and the treatment chosen for each individual.

Results: The incidence rate of AN in Iceland is 1.24/100,000. About $10 \%$ of diagnosed tumors were found incidentally. Most of those were found in the last 10 years of the investigation and in that period fewer large and giant tumors at diagnosis. Present complaints of patients at diagnosis were hearing loss (69\%), dysequilibrium/dizziness (47\%) and tinnitus
(43\%). Treatments were surgery $(n=47)$, observation $(n=30)$ and gamma knife radiosurgery $(n=16)$. We had information concerning postoperative hearing loss and facial paralysis in 39 patients who underwent surgery. Loss of hearing postoperatively occurred in 69\% $(n=27)$ and $44 \%(n=17)$ had facial paralysis. For an average of 3.5 years, $17 \%$ of tumors followed by imaging grew.

Conclusion: The incidence of $\mathrm{AN}$ is similar to that in Europe and is increasing. More tumors are found incidentally. Small tumors can be followed by regular imaging, at least for the short term. Larger tumors are treated by surgery or gamma knife radiosurgery. A high percentage of patients receiving surgery lost their hearing postoperatively.

Key words: Acoustic neuroma, acoustic tumor, vestibular schwannoma, acoustic schwannoma

Correspondence: Porsteinn H. Guðmundsson, thhg86@gmail.com

${ }^{1}$ Department of Life Sciences, University of Iceland, ${ }^{2}$ Department of Otorhinolaryngology Head and Neck Surgery, Landspítali, Reykjavik, Iceland 